\title{
Influence of Product Variables, Prices, Location and Promotions on Purchasing Decisions at Warung D'taman Restaurants in Tabanan
}

\author{
I Gede Putu Banu Astawa ${ }^{1, *}$ Nyoman Ari Surya Darmawan ${ }^{1}$ Kadek Dwi Ary \\ Kumala $^{2}$ Wenas Yohanes Berchmans ${ }^{3}$
}

\author{
${ }^{1}$ Department of Economic and Accounting, Universitas Pendidikan Ganesha, Singaraja, Indonesia \\ ${ }^{2}$ Bureau of General and Financial Affairs, Universitas Pendidikan Ganesha, Singaraja, Indonesia \\ ${ }^{3}$ Bureau of Academic, Student, Planning and Corporation Affairs, Universitas Pendidikan Ganesha, Singaraja, \\ Indonesia \\ *Corresponding author. Email: banu.astawa@undiksha.ac.id
}

\begin{abstract}
The purpose of this study was to find out the influence of product quality, price, location and promotion on purchasing decisions at Warung D'Taman Restaurant in Penebel Tabanan. In this study used a useful Causal Research Design to analyze the relationship between variables with each other. The object of his research at Warung D'taman Restaurant in Penebel,in the study was conducted directly to get primary data in the form of interview questions using questionnaires shared. With the number of research samples that respondents data as many as 100 people. The sampling technique used is accidental sampling technique. The methods of data collection in this study are questionnaires, interviews, observations and literature studies. The analytical method used in this study is a quantitative method with the help of statistical analysis tools with SPSS 23.00 software. Themethod for testing instruments is the Validity and Reliability Test, while in hypothesis testing used Test $\mathrm{t}$ and Test $\mathrm{F}$, supported by multiple linear regression analysis to find out variables that affect consumer satisfaction through data processing on the scale of variable operationalization likert. The results of hypothesis I tests are known with test $\mathrm{t}$ which shows that product variables $($ sign $=0.020)$, price $($ sign $=0.040)$ location ( $\operatorname{sign}=0.015$ and promotion $(\operatorname{sign}=0.010)$, partially affect consumer purchasing decisions at Warung D'taman restaurant in Penebel. Hypothesis II is known by looking at the results of correlation testing it is known that the Location variable becomes the dominant variable that affects the Purchase Decision $(r=0.225)$ so that the assumptions in hypothesis II are rejected, because it is not the product that is the main reason in the consumer's purchasing decision, but precisely the location, this is possible because the products from Warung D'taman Restaurant are almost the same both in the menu and the way they are presented, while the location is strategic, comfortable and safe and the area of parking is only obtained at Warung D'taman Penebel Tabanan Restaurant. The result of the acquisition of determination value $\mathrm{R}$ of $71.26 \%$ can be concluded that consumer purchasing decisions can be explained by the influence of product variables, prices, locations and promotions while the remaining $28.74 \%$ is explained by other variables such as service variables and internal and external variables in consumer behavior.
\end{abstract}

Keywords: Product quality, Price, Location, Promotion, Purchase decision.

\section{INTRODUCTION}

Restaurants with traditional cuisines that are simple or high-end or exclusive, with a variety of services provided today. Where with the many food menus served or offered and the diverse service they provide try to compete so that the restaurant is chosen and able to attract consumers to stop by. Restaurant owners try to provide satisfaction to consumers and reward their desires with the best service through the presentation of a diverse and quality menu, commensurate prices and the selection of a good and strategic restaurant location.

Consumer decisions in purchasing can be seen from several factors related to elements of the marketing mix such as Products, Prices, Promotions, but in reality individual behavior is also strongly related to internal and external factors that affect it, such as personal factors, cultural or cultural factors, social factors, and psychological factors in consumers. The decision of a 
purchase is very important for marketers because purchasing decisions can describe good or bad judgments, emotional, rational feelings and a tendency to act or act during a given time towards some object or idea. To produce a purchasing decision, consumers will usually pass the stage of introduction, information search, alternative evaluation after which it can only produce a purchase decision.

Warung Restaurant D'Taman It has only been established since 2019. located in Banjar Ubung, Penebel, Tabanan Subdistrict, which is quite unique, with a natural panorama of the countryside that is pure and original because it is located not on the side of the road utaman but entered into somewhat in in-house in Banjar Ubung with a stretch of rice fields on the right-left entrance but has garden place. The broad and very suitable for eating with family, friends or reunions and birthdays in the stalls d'park the food menu is good at an affordable price a comfortable place to enjoy nature. In reality, the restaurant stall D'Taman It's very unique and simple that it's quite in demand. consumers, with many visitors coming to enjoy the food presented in restaurant of whitening D'Taman. As a newly established stall needs a strategy in order to capture the "hearts" of enthusiasts and culinary connoisseurs, this strategy needs to be supported by aspects of scientific study in the sense of research on aspects that are expected to be influence consumer decisions that will later be a contribution of advice in the framework of the development of Warung D'Taman.

Problem Formula is there an influence between product variables, prices, locations and promotions on consumer purchasing decisions at restaurant d'taman in tabanan? Which variables are dominant in consumer purchasing decisions at restaurant d'taman in the tabanan?

\section{LITERATURE REVIEW \& HYPOTHESIS DEVELOPMENT}

The variables in this study can be traced in the basic theory that includes the concept of the Marketing Mix that is heard from some experts such as according to [1] that the marketing mix is a variable or activity that is the core of system marketing, variables that can be controlled by the company to influence the reaction of buyers or consumers. The four variable elements of the marketing mix are: Product Strategy, Price Strategy, Distribution or Distribution Strategy and Promotion Strategy. Meanwhile, according to McCarthy, quoted by [2] the simple understanding can be stated that the product (product) is a combination of goods and services offered to consumers. Price is the amount of money that must be sacrificed by consumers to obtain a product. Place (place) is activities carried out by the company so that its products are available and easily obtained by consumers.
According to [3] The Marketing Mix is a blend of products, prices, promotions and distributions used by entrepreneurs to market their products or serve their consumers, also used to influence their consumers. Where the two definitions above can be concluded that marketing mix is the core of marketing. Each element contained in the combination is interconnected and affects each other. The four variables contained in both definitions in both definitions need to be combined properly so that marketing activities can work effectively and efficiently. A product is anything that can be offered to the market for attention, demand, use or consumption that can meet a desire or need, including physical objects, services, people, organizations, ideas or ideas. In product discretion, including product planning and development, there needs to be guidelines for changing existing products (products of the same type as new models), making new products (completely new ones), or counterfeit products that are new to the company but new to the market. In addition, decisions also need to be taken regarding the issue of brand giving, packaging, color and service wisdom. Price includes price discretion, management must determine the base price of its products, then discretion regarding rebates, postage payments, price competition. Distribution includes the issue of selecting to be used to distribute its products, as well as developing a distribution system that physically handles and concerns products through those channels. This is intended so that the product can reach the market that wants to advance more effectively and efficiently. Promotion is an element that is used to inform and persuade the market about the company's new products. Advertising, individual sales and sales promotions are the main activities of promotion [4].

According to [5], the definition of consumer behavior is defined as the activities of individuals who are directly involved in obtaining and using goods and services, including the decision-making process in the preparation and determination of these activities. From the definition it can be concluded that consumer behavior contains two important elements, namely the decision-making process and physical activities that involve individuals in assessing, obtaining, and using goods and services. Consumer behavior not only observes activities that seem obvious and easily observed, which are part of the decision-making process, but should also concern the difficult and instable activities that always accompany the purchase. So, the analysis of consumer behavior must analyze activities that are clearly visible and processes that are difficult to observe and mean in addition to studying what consumers buy also learn where, how to buy it and in the conditions that the goods and services are purchased. To understand all this, a model of consumer behavior is needed. 


\subsection{Consumer Behavior Model}

Consumer behavior is very complex, especially because of the many variables that influence and the tendency to interact with each other. Whether it is from the decision-making process to buy to the decision to use a product or service. In addition, the company must also understand very well how consumers respond to marketing stimuli that the company has done. Therefore, companies and experts have made a lot of effort in researching the relationship between marketing stimuli and consumer responses.

In buying something, the consumer goes through a decision process consisting of problem recognition, information search, alternative evaluation, purchasing decisions and after-purchase behavior.

\subsubsection{Problem Recognition}

The buying process begins with the buyer recognizing a problem or need. The buyer gives a different view between his true circumstances and the circumstances he wants. At this stage marketers need to determine the circumstances that usually drive the introduction of consumer problems to find out: (a) the type of need or problem that arises, (b) what makes this sense of need arise and (c) how the need leads to a particular product.

\subsubsection{Information Search}

A consumer who has stimulated his needs can or cannot seek more information. If the impulse is strong and the object of the well-defined need is nearby, it is very likely that consumers will then buy it. An important core of marketers is the primary source of information that will be used by consumers and any influence on later purchasing decisions. Consumer information sources fall into 4 groups: 1) Personal sources: family, friends, neighbors, acquaintances. 2) Commercial sources: advertising, salespeople, merchants, packaging and exhibitions. 3) Public sources: mass media consumer assessment organizations. 4) Experimental sources: handlers, testing, and use of products

\subsubsection{Alternative Evaluation}

There are various decision evaluation processes. Certain basic concepts help give an overview to the consumer evaluation process. The first concept is product attributes. Consumers will pay the most attention to the characteristics related to their needs. The second concept, consumers may differ in giving important weights to relevant traits. A distinction can be drawn between the importance of a feature and the prominent features of the product. The third concept, consumers may develop a set of brand beliefs (brand beliefs) about where each brand is in each feature. The fourth concept, consumers are considered to have a utility function for each feature. The utility function describes how consumers expect product satisfaction to vary according to the alternative level of each trait. The fifth concept, consumers arrive at an attitude towards alternative brands through certain evaluation procedures.

\subsubsection{Buying Decision}

The decision evaluation stage allows for consumers to class objects into sets of choices. Consumers will form a buying intent and a buying decision. These factors can be seen in the following image: The first is the attitude of others. Second, the buyer's intentions are also influenced by undesirable situational factors.

\subsubsection{Behavior After Purchase}

After buying the product, consumers will experience a level of satisfaction and dissatisfaction. Consumers will also engage in after-purchase actions on marketers. The marketer's task does not end when the product has been purchased, but also continues until the period after purchase. Satisfaction or diss satisfaction with the product will provide feedback on later behavior. By understanding how buyers solve problem recognition, information search, alternative evaluation, purchasing decisions, and after-purchase behavior, marketers can find many images in relation to the gratification of buyer needs.

\subsection{Conceptual Models and Hypotheses}

With the existing marketing mix as mentioned, namely product variables, price variables, location variables and promsi variables, it is expected to be a consideration regarding consumer purchase decisions at Warung D'taman Restaurant in Penebel.

Research Hypothesis: H1: It is suspected that there is a significant influence between the variables of the marketing mix consisting of products, prices, locations and promotions to consumer purchasing decisions in buying food at Warung D'taman Restaurant in Penebel Tabanan itself. H2: It is suspected that product variables are the dominant influence on consumer purchasing decisions at Warung D'taman Restaurant in Penebel Tabanan.

\section{METHOD}

In this study using a useful Causal Research Design to analyze the relationship between one variable with another can [6]. The object of his research at Warung D'taman Restaurant in Penebel,in the study was conducted directly to get primary data in the form of interview questions using questionnaires shared. With the number of research samples that respondents' data as many as 100 people. 
The sampling technique used is accidental sampling technique, [7] that accidental sampling is a technique of determining samples from populations based on chance i.e. respondents who coincidentally meet with researchers can be used as samples when viewed as suitable as a source ofdata.

The Analytical Method used in this study is a quantitative method with the help of statistical analysis tools, as to test the Instrument is the Validity and Reliability Test, while in hypothesis testing used Test $t$ and Test F, supported by multiple linear regression analysis to find out variables that affect consumer satisfaction through data processing on the scale likert operationalization variables.

\section{RESULTS \& DISCUSSION}

In general, the characteristics of respondents at the time of the study were $63 \%$ of men, $37 \%$ of women with an age range between 20-50 years as much as $90 \%$ and over 50 years only $10 \%$ average income between Rp $1,000,000$ - Rp 2,000,000 and work (89\%), where Warung D'taman Restaurant in Penebel is very unique karn a surrounded by rice fields, So that Warung D'taman Restaurant is very favorite for young people that is not only able to enjoy good and unique food there is also a good place and can take pictures because it is a good photo place.

From the processing of statistics on the instrument it is obtained that all instruments poured in 15 items can be declared valid. While reliability testing obtained reliable values in Table 1 . The results of respondents' responses in each product variable research instrument obtained information that $86 \%$ of respondents agreed with statements about the taste of good cuisine, available various menus and clean ways of serving.

Price Variables can be known that $89 \%$ stated the price is quite affordable and in accordance with the quality of taste, while $92 \%$ said they agree with the existence of a strategic location on the edge of the rice field with a comfortable atmosphere and place and the existence of facilities that are wide enough, making it easier for two- and four-wheeled vehicles to park without having to worry about safety. Variable Promotion obtained information that $80 \%$ of respondents said that they knew the existence of Warung D'taman Restaurant in Penebel through information from social media uploaded on Instagram and other social media, they as well as a fairly interesting and clear display of signage installed in front of the street to Warung D'taman Restaurant in Penebel. The test results with the help of SPSS software can be seen in Table 2 .

The results of hypothesis I tests are known with test $t$ which shows that product variables $($ sign $=0.020)$, price $(\operatorname{sign}=0.040)$ location $($ sign $=0.015$ and promotion $($ sign $=0.010$ ), partially affect consumer purchasing decisions at Warung D'taman restaurant in Penebel. Hypothesis II is known by looking at the results of correlation testing it is known that the Location variable becomes the dominant variable that affects the Purchase Decision ( $\mathrm{r}=$ 0.225 ) so that the assumptions in hypothesis II are rejected, because it is not the product that is the main reason in the consumer's purchasing decision, but precisely the location, this is possible because the

Table 1. The Result Reliability Test

\begin{tabular}{|c|c|c|c|}
\hline No & Instrument Results & Information & Reliability \\
\hline 1 & 0,626 & Saw & \multirow{15}{*}{$\begin{array}{l}r \text { Alpha }=0,7180 \\
\text { table } r=0,2407 \\
r \text { Alpha }>\text { r table } \\
\text { Where }\end{array}$} \\
\hline 2 & 0,742 & Saw & \\
\hline 3 & 0,469 & Saw & \\
\hline 4 & 0,829 & Saw & \\
\hline 5 & 0.546 & Saw & \\
\hline 6 & 0,605 & Saw & \\
\hline 7 & 0.575 & Saw & \\
\hline 8 & 0,456 & Saw & \\
\hline 9 & 0,545 & Saw & \\
\hline 10 & 0,875 & Saw & \\
\hline 11 & 0,826 & Saw & \\
\hline 12 & 0,677 & Saw & \\
\hline 13 & 0,706 & Saw & \\
\hline 14 & 0,668 & Saw & \\
\hline 15 & 0,855 & Saw & \\
\hline
\end{tabular}


Table 2. The Result of SPSS Program

\begin{tabular}{|l|c|c|c|c|}
\hline \multicolumn{1}{|c|}{ Variable } & $\mathrm{B}$ & $\mathrm{t}$ & Have & $\mathrm{r}$ \\
\hline Constant (a) & 5,312 & 3,855 & 0,000 & 1,000 \\
Product & 0,324 & 2,365 & 0,020 & 0,137 \\
Price & 0,346 & 2,082 & 0,040 & 0,195 \\
Location & 0,356 & 3,478 & 0,015 & 0,225 \\
Promotion & 0,304 & 2,469 & 0,010 & 0,220 \\
\hline & $\mathrm{R}=7.126$ & $\mathrm{~F}=4.624$ & 0,000 & \\
\hline
\end{tabular}

products from Warung D'taman Restaurant are almost the same both in the menu and the way they are presented, while the location is strategic, comfortable and safe and the area of parking is only obtained at Warung D'taman Penebel Tabanan Restaurant.

The result of the acquisition of determination value $\mathrm{R}$ of $71.26 \%$ can be concluded that consumer purchasing decisions can be explained by the influence of product variables, prices, locations and promotions while the remaining $28.74 \%$ is explained by other variables such as service variables and internal and external variables in consumer behavior.

\section{CONCLUSION}

Warung D'taman restaurant is located in Banjar, Ubung, Penebel, Tabanan Subdistrict, can be said to be a new restaurant that is quite unique and with a spacious parker place suitable for eating with family, friends or reunion and birthdays In warung d'taman the food menu is good at affordable prices a comfortable place to enjoy nature. The results of hypothesis I tests are known with test $\mathrm{t}$ which shows that product variables $(\operatorname{sign}=0.020)$, price $(\operatorname{sign}=0.040)$ location $(\operatorname{sign}=0.015$ and promotion $($ sign $=0.010)$, partially affect consumer purchasing decisions at Warung D'taman restaurant in Penebel. Hypothesis II is known by looking at the results of correlation testing it is known that the Location variable becomes the dominant variable that affects the Purchase Decision $(r=0.225)$ so that the assumptions in hypothesis II are rejected, because it is not the product that is the main reason in the consumer's purchasing decision, but precisely the location, this is possible because the products from Warung D'taman Restaurant are almost the same both in the menu and the way they are presented, while the location is strategic, comfortable and safe and the area of parking is only obtained at Warung D'taman Penebel Tabanan Restaurant. The result of the acquisition of determination value $\mathrm{R}$ of $71.26 \%$ can be concluded that consumer purchasing decisions can be explained by the influence of product variables, prices, locations and promotions while the remaining $28.74 \%$ is explained by other variables such as service variables and internal and external variables in consumer behavior.
Based on the conclusions taken, the advice that can be given by researchers is as follows: 1) It is expected that Warung D'Taman Restaurant to maintain the cleanliness of food and beverages served so that consumers feel confident to make purchases at Warung D'Taman Restaurant and it is expected that Warung D'Taman Restaurant serves more food and beverage portions in accordance with what is expected by consumers. 2) It is expected that Warung D'Taman Restaurant to maintain the quality of taste of the food and drinks served because the majority of consumers do not mind the expensive price if the food and drinks they buy have good quality and it is expected that Warung D'Taman Restaurant will reestimate prices so that prices are set in accordance with the expectations and desires of the umen. 3) It is expected that Warung D'Taman Restaurant to maintain the existence of the current location because consumers are quite familiar with the location of Warung D'Taman Restaurant and use the empty land around Warung D'Taman Restaurant to be used as a parking lot for consumers or customers who will visit and buy at Warung D'Taman Restaurant. 4) It is expected that Warung D'Taman Restaurant will promote through social media in hopes of creating closer relationships with consumers and conducting more vociferous promotions in both radio and newspapers. 5) Based on the results of this study, researchers suggest that researchers should further develop this study using other variables that can influence purchasing decisions.

\section{REFERENCES}

[1] S. Assauri, Basic Marketing Management concept and strategy. Jakarta: Rajawali Press, 1987.

[2] P. Kotler and Armstrong, Marketing Management Planning and Control Analysis. Jakarta: Erlangga, 1993.

[3] I. Gitosudarmo, Marketing Management. Yogyakarta: BPFE, 1995.

[4] J. W. Stanton, Marketing Principles I, Seventh Edition. Jakarta: Erlangga, 1996.

[5] B. Swastha and T. H. Handoko, Manajemen. Pemasaran Analisa Perilaku Konsumen. Yogyakarta: BPFE, 1982. 
[6] H. Umar, Marketing Research and Consumer Behavior. Jakarta: PT Gramedia Pustaka Utama, 2000.

[7] Sugiyono, Statistics for research. Bandung: Alfabeta, 2003. 